Jurnal

Kardiologi Indonesia

J Kardiol Indones. 2014;35:50-8

ISSN 0126/3773

\title{
Management of Diastolic Heart Failure
}

\author{
Starry H. Rampengan
}

Department of Cardiology and Vascular Medicine, Faculty of Medicine, University of Sam Ratulangi and RS Kandou, Manado
The diastolic heart failure also referred to as heart failure with preserved left ventricular systolic function (preserved ejection fraction). The difference between systolic and diastolic HFs is a pathophysiological one and isolated forms of left ventricular dysfunction are rarely observed. In diastolic HF left ventricular systolic function is normal or only slightly impaired, and the typical manifestations of HF result from increased filling pressure caused by impaired relaxation and compliance of the left ventricle. The management should include antihypertensive treatment, maintenanceof the sinus rhythm, prevention of tachycardia, venous pressure reduction, prevention of myocardial ischemia and prevention of diabetes mellitus. Treatment of diastolic $\mathrm{HF}$ is aimed to stop the progression of the disease, relieve its symptoms, eliminate exacerbations and reduce the mortality. The predisposing factors for diastolic dysfunction include elderly age, female sex, obesity, coronary artery disease, hypertension and diabetes mellitus. The European Society of Cardiology specifies the type of therapy in diastolic HF based on: angiotensin converting enzyme inhibitors, angiotensin receptor blockers, beta-blockers, non dihydropyridine calcium channel blockers, diuretics.

(J Kardiol Indones. 20 I4;34:50-8)

Keywords: Diastolic heart failure, management 


\title{
Penanganan Gagal Jantung Diastolik
}

\author{
Starry H. Rampengan
}

\begin{abstract}
Gagal jantung diastolik disebut juga sebagai gagal jantung dengan fungsi sistolik ventrikel kiri yang normal (ejeksi fraksi normal). Perbedaan antara gagal jantung sistolik dan diastolik terletak pada patofisiologinya. Pada gagal jantung diastolik fungsi ventrikel kiri normal atau sedikit menurun dan manifestasi yang timbul disebabkan oleh peningkatan tekanan pengisian yang disebabkan oleh gangguan relaksasi dan komplains ventrikel kiri. Manajemen gagal jantung diastolik meliputi terapi antihipertensi, pemeliharaan irama sinus, pencegahan takikardi, pengurangan tekanan vena, pencegahan iskemik miokard dan pencegahan diabetes melitus. Terapi gagal jantung diastolik bertujuan untuk mengurangi progresivitas, menghilangkan gejala, mencegah eksaserbasi dan menurunkan angka mortalitas. Faktor predisposisi disfungsi diastolik meliputi usia lanjut, jenis kelamin wanita, obesitas, penyakit jantung koroner, hipertensi dan diabetes melitus. The European Society of Cardiology mengeluarkan beberapa macam penatalaksanaan gagal jantung diastolik berdasarkan: ACE-inhibitors, angiotensin receptor blocker, beta bloker, calcium channel bloker non dibidropiridin, diuretik.
\end{abstract}

(J Kardiol Indones. 2014;35:50-8)

Kata kunci: Gagal jantung diastolik, penatalaksanaan

\section{Pendahuluan}

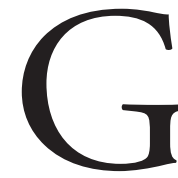

agal jantung kongestif merupakan salah satu penyebab rawat inap tersering di dunia. Biasanya pasien gagal jantung disertai dengan pembesaran jantung dan penurunan fungsi sistolik, tetapi sekitar $50 \%$ pasien gagal jantung mempunyai fungsi sistolik yang normal atau hanya sedikit terganggu yang didiagnosis dengan gagal jantung diastolik atau disebut juga dengan heart failure with preserved ejection fraction (HFPEF). ${ }^{1,2}$

\section{Alamat Korespondensi}

dr. Starry H. Rampengan, SpJP. Fakultas Kedokteran Unsrat/BLU RSUP Prof dr RD Kandou Manado. E-mail: starry8888@yahoo. com
Pada HFPEF fungsi sistolik ventrikel kiri bisa normal atau sedikit menurun (fraksi ejeksi pada ekokardiografi $\geq 40 \%$ ), sedangkan pada gagal jantung sistolik, kontraktilitas dari ventrikel kiri sangat menurun. Pada HFPEF manifestasi klinis muncul karena peningkatan tekanan pengisian yang disebabkan gangguan relaksasi dan komplains ventrikel kiri yang menurun.

Perbedaan antara dua jenis gagal jantung ini juga diamati pada tingkat selular. Van Heerebeek et al. ${ }^{3}$ menunjukkan bahwa pada HFPEF sering kali didapatkan elongasi dari miosit jantung dengan peningkatan resting tone. Kekakuan pada dinding dan penurunan komplians dari miokardium merupakan akibat dari meningkatnya jumlah kolagen pada lapisan interstisial. ${ }^{3,4}$

Curah jantung tidak hanya bergantung pada fraksi ejeksi tetapi juga pada volume diastolik. Pada 
disfungsi diastolik terjadi disfungsi diastolik ventrikel kiri, menyebabkan peningkatan resistensi pengisian ventrikel kiri dan akhirnya mengakibatkan gagal jantung. Gangguan relaksasi ventrikel dan peningkatnya tahanan pada ventrikel merupakan mekanisme terjadinya disfungsi diastolik. Kardiomiopati hipertrofi merupakan contoh klasik dari gejala gagal jantung dengan fungsi sistolik yang masih sangat baik. ${ }^{4}$

\section{Diagnosis}

Diagnosis dari HFPEF dapat ditegakkan bila pada pasien didapatkan gejala-gejala khas dari gagal jantung, pada pemeriksaan fisik menunjukkan adanya kongesti vena dan kongesti paru atau bahkan edema paru dan pada ekokardiografi menunjukkan fraksi ejeksi yang normal atau sedikit menurun. Menurut European Society of Cardiology (ESC), diagnosis gagal jantung diastolik harus memperhatikan tiga hal sebagai berikut ${ }^{1}$ :

1. Ada atau tidaknya gejala gagal jantung kongesti (intoleransi latihan adalah tanda pertama dari kegagalan diastolik, seperti peningkatan denyut jantung selama latihan memperpendek durasi pengisian ventrikel kiri yang sudah terganggu dan menyebabkan kelebihan tekanan pada sirkulasi pulmonal); bagaimanapun harus diingat bahwa identifikasi bentuk gagal jantung tidak mungkin hanya berdasarkan gejala saja, sebagai diagnosa deferensial harus mencakup beberapa kondisi berikut :

- Kondisi kardiovaskular: penyakit jantung iskemik, penyakit jantung katup, kardiomiopati hipertrofi dan restriktif, dan pericarditis konstriktif,

- Kondisi non-kardiak: penyakit paru, obesitas, anemia, hiperventilasi, hipertiroidism, hipertensi pulmonal;

2. Adanya fungsi sistolik ventrikel kiri yang normal atau hanya sedikit abnormal fraksi ejeksi $>40-50 \%$; fraksi ejeksi merupakan parameter yang paling penting dalam membedakan gagal jantung sistolik dan diastolik;

3. Didapatkan adanya gangguan relaksasi, pengisian, dan komplians diastolik dan kekakuan diastolik pada ventrikel kiri.

Parameter di atas terutama dinilai berdasarkan ekokardiografi. Tanda-tanda disfungsi diastolik yang ditemukan pada ekokardiografi antara lain abnormalitas dari fase diastolik di mitral inflow (pada pasien dengan irama sinus normal), profil aliran darah pada vena pulmonalis dan rasio kecepatan awal pengisian mitral dan kecepatan awal diastolik anulus mitral (E/E') diukur dengan tissue doppler ekokardiografi. ${ }^{5}$

Faktor predisposisi dari disfungsi diastolik meliputi usia lanjut, obesitas, hipertensi dan diabetes mellitus. Resiko terjadinya HFPEF juga meningkat pada pasien dengan penyakit arteri koroner selama beberapa tahun, pasien dengan riwayat sindroma koroner akut dan pasien dengan riwayat miokarditis. Sebagian besar pasien dengan HFPEF adalah pasien dengan hipertrofi ventrikel kiri yang disebabkan oleh berbagai etiologi: pada kardiomiopati hipertrofi, aorta stenosis, penyakit ginjal kronis dengan komplikasi hipertensi. ${ }^{3}$

Prognosis akan memburuk dengan bertambahnya usia. Sebuah analisis dari beberapa studi menunjukkan bahwa selama periode lima tahun persentase pasien HFPEF yang meninggal adalah $15 \%$ di antaranya yang berusia di bawah 50 tahun, $33 \%$ berusia $50-70$ tahun, dan 50\% berusia lebih dari 70 tahun. Menurut Aurigemma ${ }^{6}$ kelangsungan hidup pasien dengan HFPEF hanya sedikit lebih lama dibandingkan dengan pasien dengan disfungsi sistolik.

\section{Penatalaksanaan}

Pengobatan HFPEF ditujukan untuk menghentikan progresifitas dari penyakit, meringankan gejala, mencegah eksaserbasi dan mengurangi angka kematian. Kesuksesan pengobatan gagal jantung tergantung pada ditemukannya etiologi gagal jantung tersebut. Ekokardiografi adalah alat diagnostik utama, ekokardiografi banyak tersedia, banyak diproduksi dan tidak mahal, dan hasilnya dilengkapi oleh hasil elektrokardiografi dan foto x-ray dada. Panduan dari American College of Cardiology (ACC) dan American Heart Association ( $A H A$ ) menekankan bahwa pengukuran brain natriuretic peptide (BNP) dan N-terminal pro B-type natriuretic peptide (NTproBNP) sangat membantu dalam stratifikasi resiko pada pasien dengan disfungsi diastolik dan sistolik ventrikel kiri, meskipun tidak boleh digunakan sebagai penanda keberhasilan pengobatan (rekomendasi kelas IIa). Pernyataan ini berdasarkan fakta bahwa pengukuran BNP untuk memonitor pengobatan tidak bisa dikaitkan dengan penurunan angka kematian. ${ }^{7}$ Sementara obat-obatan seperti angiotensin converting 
Starry R: Tatalaksana gagal jantung diastolik

Tabel 1. Karakteristik Gagal Jantung Diastolik Dibandingkan Gagal Jantung Sistolik7

\begin{tabular}{lll}
\hline Karakteristik & Gagal Jantung Diastolik & Gagal Jantung Sistolik \\
\hline Klinis & Ya & \\
Gejala (contoh:sesak nafas) & Ya & Ya \\
Kongesti (contoh:edema) & Ya & Ya \\
$\begin{array}{l}\text { Aktifasi neurohormonal (contoh:BNP) } \\
\text { Fungsi dan struktur ventrikel kiri }\end{array}$ & Ya \\
\hline Fraksi ejeksi & Normal & Menurun \\
Massa ventrikel kiri & Meningkat & Meningkat \\
Ketebalan relatif dinding & Meningkat & Menurun \\
Volume akhir diastolik & Normal & Meningkat \\
Tekanan akhir diastolik & Meningkat & Meningkat \\
Ukuran atrium kiri & Meningkat & Meningkat \\
Aktifitas & & \\
Kapasitas latihan & Menurun & Menurun \\
Curah jantung & Menurun & Menurun \\
Tekanan akhir diastolik & Meningkat & meningkat \\
\hline
\end{tabular}

enzyme (ACE) inhibitor, angiotensin receptor blocker (ARBs), beta blockers, aldosterone antagonis dan diuretik ditetapkan sebagai pengobatan untuk gagal jantung sistolik, penggunaan obat ini pada HFPEF tidak didukung oleh studi multipel. Menurut panduan dari AHA/ACC, pengobatan dari HFPEF harus meliputi ${ }^{1,7}$ :

- Terapi untuk hipertensi

- Pemeliharaan irama sinus

- Mencegah terjadinya takikardia

- Penurunan tekanan vena

- Pencegahan terjadinya iskemia miokard

Terapi kausatif, bila digunakan pada tahap awal penyakit, sebaiknya di tahap A ( resiko tinggi terjadinya gagal jantung tanpa adanya gejala) merupakan yang paling efektif. Terapi yang efektif untuk hipertensi, penyakit arteri koroner dan diabetes mellitus menurunkan resiko terjadinya komplikasi lebih lanjut. ${ }^{1,7}$

\section{Penanganan Hipertensi}

Terapi anti-hipertensi merupakan elemen pengobatan yang paling penting, karena diperkirakan bahwa hipertensi diderita oleh sekitar $60 \%$ pasien dengan HFPEF. Korelasi erat antara dua penyakit ini mendukung terapi anti-hipertensi yang intensif. Bagaimanapun, harus diingat bahwa pasien usia lanjut mendominasi kelompok ini dan sangat penting untuk menghin- dari penurunan tekanan darah secara cepat. Hal ini penting karena fungsi saraf otonom yang sudah terganggu dan resiko terjadinya hipertensi postural. Normalisasi tekanan darah sistolik membuat afterload yang lebih rendah sehingga mengurangi beban ventrikel kiri, yang nantinya akan mengakibatkan penurunan volume diastolik ventrikel kiri dan tekanan atrium kiri. Keuntungan tidak langsung dari normalisasi tekanan darah yaitu perbaikan keseimbangan oksigen pada miokardium dengan peningkatan perfusi miokardial dan relaksasi yang lebih cepat. Manfaat tidak langsung didapatkan dari penekanan atau pengurangan hipertrofi ventrikel kiri dan dari penurunan persentase dari kolagen pada dinding ventrikel kiri. ${ }^{3,6}$

Pemilihan obat yang akan digunakan sebagai terapi untuk edema paru pada hipertensi harus berdasarkan pada onset kerja obat. Penanganan pasien harus meliputi terapi oksigen, morfin, diuretik intravena, dan glyceryl trinitrate (GTN). Namun harus diingat bahwa penggunaan diuretik secara agresif dan GTN pada pasien dengan WMSI akan mengakibatkan hipotensi yang berbahaya sebagai akibat dari penurunan cepat tekanan pengisian ventrikel kiri dan penurunan curah jantung. Pemilihan obat anti-hipertensi dengan penggunaan lama pada pasien dengan HFPEF harus memperhatikan peran angiotensin dalam proses terjadinya hipertrofi ventrikel kiri dan perubahan struktural pada dinding ventrikel kiri berkaitan dengan peningkatan kolagen. Mempertimbangkan aspek menejemen ini, obat pilihannya meliputi $A C E$ inhibitor, AT1 receptor blockers dan aldosterone antagonist. Warner 
et $\mathrm{al}^{8}$ menunjukkan bahwa kapasitas latihan yang terbatas adalah konsekuensi dari peningkatan tekanan darah, maka tujuan dasar dari terapi harus mencegah peningkatan tekanan darah selama latihan.

Pada studi Losartan Intervention For Endpoint reduction in hypertension $(L I F E)^{9}$, pada grup pasien dengan hipertensi dan hipertrofi ventrikel kiri, suatu keberhasilan yang lebih tinggi dari losartan $v$ s atenolol ditunjukkan dalam penurunan primary endpoint (kematian akibat kardiovaskular, infark miokard atau stroke; $p=0,021)$ dan regresi hipertrofi ventrikel kiri yang diukur dengan ekokardiografi $(\mathrm{p}<0,0001)$.

Studi Candesartan in Heart failure: assessment of Reduction in Mortality and morbidity-Preserved (CHARM-Preserved) ${ }^{10}$ membandingkan efek dari candesartan vs placebo pada grup pasien NYHA klas II,III,IV dengan fraksi ejeksi $>40 \%$. Dari 3023 pasien, 1514 dipilih secara acak diberi terapi dengan Candesartan (dosis target $32 \mathrm{mg} /$ hari) dan 1509 diberikan placebo. Primary endpoint adalah kematian karena kardiovaskular atau angka rawat inap karena gagal jantung. Selama periode 36,6 bulan primary endpoint terjadi pada $333(22 \%)$ pasien yang diberikan Candesartan dan 366 (24\%) pasien yang menerima placebo $(\mathrm{p}=0,051)$. Kematian karena penyakit kardiovaskular terjadi pada kedua kelompok dengan sebanyak 170 pasien. Angka rawat inap karena gagal jantung lebih sedikit pada grup yang diberikan candesartan daripada placebo (230 vs 279, $\mathrm{p}=0,017) .{ }^{10}$

Studi lain yang mengevaluasi manfaat terapi dengan ACE inhibitor adalah studi Perindopril In Elderly People With Chronic Heart Failure (PEP-CHF) ${ }^{11}$ Total 850 pasien usia $\geq 70$ tahun dengan gejala HFPEF dipilih secara acak diberikan terapi perindopril $4 \mathrm{mg}$ atau placebo. Primary endpoint meliputi semua sebab kematian dan kejadian rawat inap yg tidak terencana untuk gagal jantung. Rata-rata lama pemantauan adalah 26,2 bulan. Primary endpoint timbul pada 107 pasien yang diberikan placebo dan 100 pasien yang diberikan perindopril $(\mathrm{p}=0,545)$. Efek dari terapi perindopril lebih menguntungkan pada tahun awal dilakukan studi. Pada periode ini primary endpoint didapatkan pada 65 $(15,3 \%)$ pasien dengan placebo dan $46(10,8 \%)$ pasien dengan perindopril $(\mathrm{p}=0,055)$, dan angka rawat inap karena gagal jantung lebih rendah pada grup pasien yang diberikan perindopril $(\mathrm{p}=0,033)$. Angka kematian pada kedua grup hampir sama. Perbaikan yang signifikan kelas NYHA terjadi pada pasien yang diberikan perindopril $(\mathrm{p}<0,030)$. Ada juga peningkatan yang signifikan dalam jarak jalan kaki selama enam menit pada kelompok yang diberikan perindopril $(\mathrm{p}=0,011)$. Pengobatan dengan perindopril tidak mempengaruhi tingkat NT-proBNP. ${ }^{11}$

Berdasarkan pada hasil-hasil penelitian di atas dapat disimpulkan bahwa terapi farmakologis pada sistem renin-angiotensin-aldosterone dapat mengakibatkan peningkatan kapasitas latihan pada pasien dengan HFPEF dan mungkin juga menurunkan resiko rawat inap untuk gagal jantung tetapi tidak mempengaruhi prognosis. Ketika membahas tentang hasil dari studi PEP-CHF kami menyimpulkan bahwa keparahan dari gagal jantung pada studi populasi adalah ringan, sebagaimana dibuktikan oleh tingkat NT-proBNP (rata-rata nilai pada grup dengan placebo dan grup dengan perindopril adalah $453 \mathrm{pg} / \mathrm{mL}$ dan $335 \mathrm{pg} / \mathrm{mL}$ ). Juga angka komplikasi yang relatif rendah, jauh lebih rendah dari yang diharapkan, dapat mendukung hipotesis di atas. Untuk melihat penurunan yang signifikan dari angka kematian pada populasi, ke depannya diperlukan pemantauan yang lebih lama dan memperbanyak jumlah sampel. ${ }^{11,12}$

Para peneliti melakukan studi Valsartan In Diastolic Dysfunction (VALIDD) ${ }^{12}$ dengan valsartan menunjukkan fakta bahwa penurunan tekanan darah dapat meningkatkan fungsi diastolik miokardium pada pasien hipertensi tanpa gagal jantung dan bahwa efek ini merupakan independen dari jenis anti-hipertensi yang digunakan.

Panduan dari ACC/AHA menempatkan kontrol tekanan darah sistolik dan diastolik pada kelas tertinggi rekomendasi untuk penanganan HFPEF (kelas Ia). ${ }^{7}$ Efek dari normalisasi tekanan darah meliputi :

- Penurunan tekanan akhir diastolik;

- Penurunan tekanan atrium kiri;

- Perbaikan dari relaksasi yang mengarah ke peningkatan pengisian awal;

- Pengurangan pada iskemia miokard (dengan mengurangi kebutuhan oksigen dan meningkatkan perfusi sebagai hasil dari penurunan tekanan akhir diastolik);

- Pengurangan hipertrofi ventrikel kiri dan menghasilkan pengurangan resiko terjadi atau perburukan dari gagal jantung.

Pada studi Systolic Hypertension in the Elderly Program (SHEP) ${ }^{13}$ menunjukkan bahwa kontrol yang bagus dari hipertensi sistolik terisolasi secara signifikan menurunkan resiko terjadinya gagal jantung dan 
menyebabkan pengurangan indeks massa ventrikel kiri sebanyak $13 \%$. Pengobatan didasarkan pada chlorthalidone dan atenolol. ${ }^{13,14}$

\section{Pemeliharaan Irama Sinus dan Pencegahan Takikardi}

Panduan dari ACC/AHA menempatkan kontrol irama ventrikel pasien dengan atrial fibrilasi $(\mathrm{AF})$ dan pengembalian irama sinus pada pasien dengan AF pada kelas rekomendasi II dengan tingkat bukti A. ${ }^{7}$

Dengan kondisi fisiologis denyut jantung meningkat menyebabkan relaksasi dan sedikit menurunkan tekana diastolik pada ventrikel (gambar 1). Pada gagal jantung diastolik, takikardi menimbulkan relaksasi yang tertunda dan peningkatan tekanan diastolik.

Selain itu, kontribusi persentase diastolik dalam kaitannya dengan penurunan sistolik dengan peningkatan denyut jantung. Porsi diastolik hampir $70 \%$ dari siklus jantung pada denyut jantung $60 \mathrm{kali} / \mathrm{menit}$, sekitar $50 \%$ pada denyut jantung $120 \mathrm{kali} /$ menit dan hanya $40 \%$ pada denyut jantung $180 \mathrm{kali} / \mathrm{menit}$. Oleh karena itu waktu pengisian ventrikel kiri dipersingkat. Penurunan denyut jantung menghasilkan penurunan tekanan pada periode awal dari fase diastolik dengan meningkatkan relaksasi dan meningkatkan waktu pengisian ventrikel kiri yang akhirnya meningkatkan curah jantung. Waktu perfusi koroner juga meningkat bersamaan dengan menurunnya konsumsi oksigen oleh miokardium dan meningkatkan suplai darah pada miokard. Para pakar di ESC merekomendasikan penggunaan beta-blocker atau calcium channel blockers (CCB) untuk mengurangi denyut jantung. ${ }^{15}$

Studi Swedish Doppler-echocardiographic (SWEDIC) ${ }^{16}$ meneliti efek dari penggunaan carvedilol selama 6 bulan pada 97 pasien hipertensi dengan parameter fungsi diastolik pada ekokardiografi. Ditemukan adanya perbaikan yang signifikan dibandingkan dengan placebo pada rasio E/A dari 0,72 ke 0,83 ( $\mathrm{p}=0,046)$.

Pada salah satu publikasi sebelumnya ditunjukkan adanya manfaat penggunaan verapamil intravena dengan parameter pengisian ventrikel kiri pada pasien dengan kardiomiopati hipertrofi. ${ }^{16}$

Memperhatikan hubungan dekat antara tekanan pengisian ventrikel kiri dan kapasitas latihan pada pasien, penurunan denyut jantung pada HFPEF harus diprioritaskan. Pada pasien dengan HFPEF, jantung sudah tidak mampu untuk mengambil manfaat dari mekanisme Frank-Starling selama latihan atau aktifitas fisik. Pada ventrikel yang kaku, meskipun tekanan pengisian meningkat tetapi tidak dapat meningkatkan volume. Sebagai konsekuensinya terjadi peningkatan tekanan pengisian ventrikel tetapi curah jantung tidak meningkat. Oleh karena itu dengan menurunkan irama ventrikel maka curah jantung dapat meningkat. Gejala

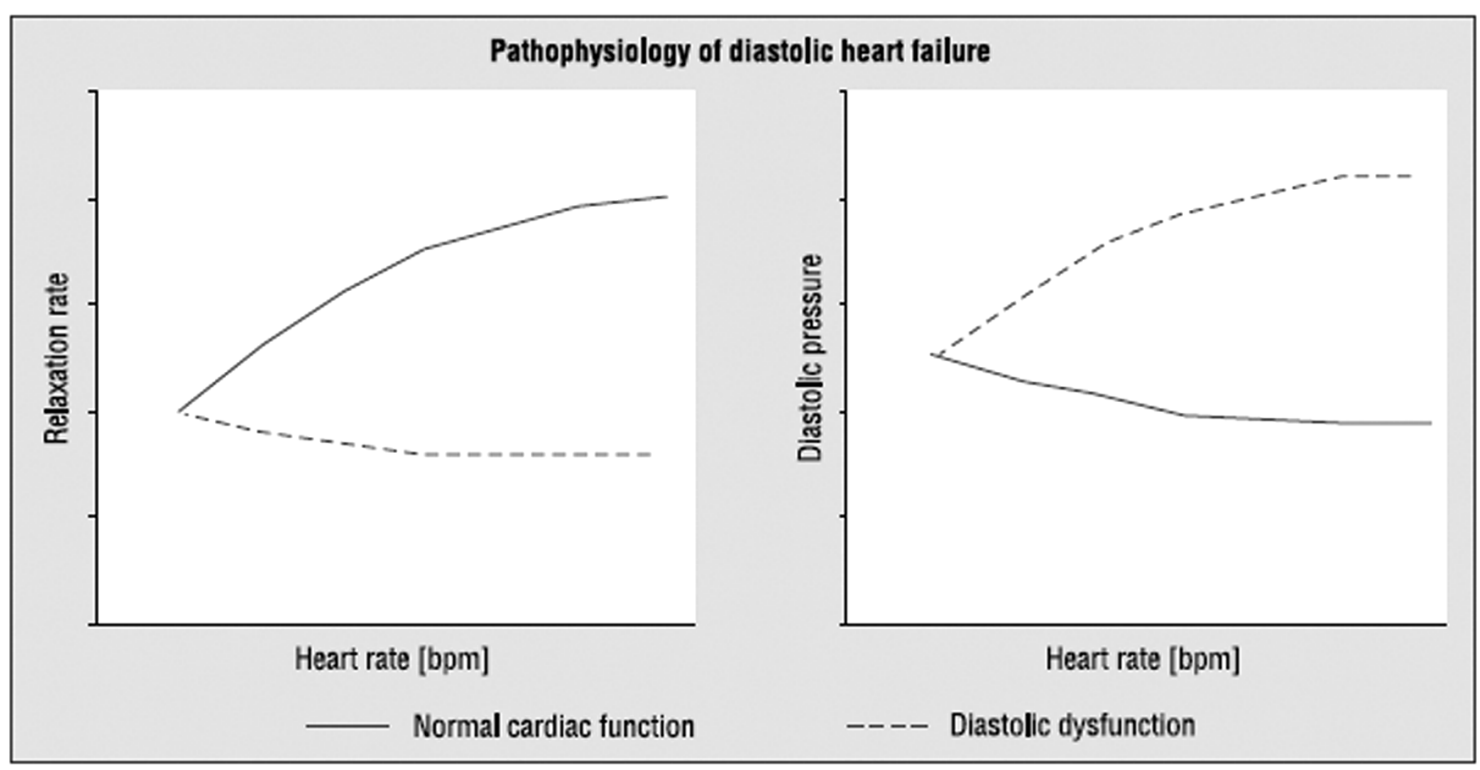

Gambar 1. Hubungan antara relaksasi dan antara tekanan diastolik ventrikel kiri dan denyut jantung pada kondisi fisiologis dan pada gagal jantung diastolik. 
ini mungkin dapat dihilangkan dengan pemberia betablocker dan CCB. Pada Study of Effects of Nebivolol Intervention on Outcomes and Rehospitalization in Seniors With Heart Failure (SENIORS) ${ }^{17}$ nebivolol secara signifikan menurunkan resiko kematian dan angka rawat inap pada kedua grup pasien dengan gagal jantung dan fraksi ejeksi yang menurun dan juga pada grup pasien dengan fraksi ejeksi yang normal.

Perbedaan penting pada penanganan kedua tipe gagal jantung terletak pada penggunaan CCB dihidropiridine, yang bermanfaat untuk terapi pada disfungsi diastolik. CCB dihidropiridin mempunyai efek relaksasi miokardium, selain itu juga dapat menurunkan tekanan darah dan denyut jantung. ${ }^{15}$

Peran digitalis dalam penatalaksanaan HFPEF masih kontroversial, terutama dalam hal mempertahankan irama sinus. Dalam studi Digitalis Investigation Group $(\mathrm{DIG})^{18}$ sebanyak 988 pasien dengan gagal jantung mempunyai fraksi ejeksi $>45 \%, 492$ diantaranya secara acak diberikan digoxin dan 496 diberikan placebo. Keuntungan dari penggunaan digitalis pada grup ini sama dengan pasien yang mempunyai fraksi ejeksi yang menurun. Namun demikian, diyakini secara luas bahwa penggunaan digitalis pada HFPEF harus dibatasi untuk pasien dengan AF, dan tujuan utama dari penggunaan obat ini adalah untuk kontrol irama ventrikel. Digitalis tidak boleh digunakan bila irama sinus masih dapat dipertahankan.

Harus diingat bahwa gangguan pengisian ventrikel kiri pada disfungsi diastolik dapat semakin diperparah oleh irama non sinus, oleh karena itu menghilangkan aritmia seperti $\mathrm{AF}$ atau atrium fluter adalah elemen pengobatan yang penting. Bila irama sinus tidak dapat dipertahankan, mungkin dapat dipertimbangkan melakukan ablasi atrioventrikular node atau pemasangan pacemaker. ${ }^{18}$

\section{Penurunan Tekanan Vena}

Peningkatan dari tekanan arteri pulmonal sebanyak $1 \mathrm{mmHg}$ akan mengakibatkan peningkatan 23\% angka kematian dan $13 \%$ angka terjadinya kejadian kardiovaskular. Dengan menurunkan tekanan pulmonal, kapasitas latihan dan prognosis akan meningkat. Kesulitan dalam mengoptimalkan tekanan pengisian ventrikel kiri pada HFPEF dikarenakan pada pasien HFPEF mempunyai kurva tekanan ataupun volume yang berbeda dari kurva fisiologis. Pada pasien dengan HFPEF meskipun ada penurunan tekanan pengisian ventrikel kiri sedikit saja akan menimbulkan penurunan volume diastolik ventrikel kiri yang bermakna yang pada akhirnya terjadi penurunan signifikan pada curah jantung. Peningkatan tekanan pengisian seringkali gagal secara signifikan mempengaruhi curah jantung tetapi mungkin dapat menyebabkan edema paru. ${ }^{8,19}$

Pasien dengan HFPEF menunjukkan kecenderungan ke arah retensi cairan, oleh karena itu disarankan melakukan pembatasan diet garam dan cairan, semetara itu diuretik merupakan andalan untuk pengobatan simtomatik. Mengingat akan resikonya, maka diperlukan kewaspadaan dalam penggunaan diuretik atau nitrat kerja panjang, terutama pada fase awal pengobatan penggunaan obat ini harus dibawah pengawasan ketat dari tenaga medis. Diuretik tidak mempengaruhi miokardium secara langsung, sedangkan nitrat meningkatkan kemampuan ventrikel kiri untuk meningkatkan volumenya dengan melepaskan nitrogen nitrat. ${ }^{7,15}$

Efek penurunan tekanan vena meliputi :

- Menurunkan kompresi ventrikel kiri $\rightarrow$ meningkatkan fungsi;

- Menurukan tekanan akhir diastolik ventrikel kiri $\rightarrow$ meningkatkan kapasitas latihan

- Meningkatkan keseimbangan oksigen pada miokardium $\rightarrow$ menghilangkan iskemia

Pengobatan diatas memerlukan perhatian karena resiko terjadinya dehidrasi yang akan mengakibatkan low-output syndrome, hipotensi, dan gangguan fungsi ginjal. Dosis obat-obatan yang dapat menyebabkan dehidrasi ini lebih rendah dibandingkan pada pasien dengan disfungsi sistolik. Spironolakton merupakan obat menggabungkan diuretik dengan efek menguntungkan pada struktur ventrikel kiri. ${ }^{9}$

\section{Pencegahan Iskemia}

Iskemia miokard merupakan salah satu mekanisme penting yang mendasari HFPEF. Oleh karena itu dibenarkan untuk menggunakan obat yang mempunyai efek mengurangi konsumsi oksigen miokardium (beta blocker, CCB, nitrates) dan revaskularisasi untuk meningkatkan suplai oksigen ke miokardium. ${ }^{18}$

Peningkatan suplai oksigen ke miokardium menyebabkan meningkatnya relaksasi, menurunnya tekanan akhir diastolik ventrikel kiri, mengurangi 
resiko terjadinya aritmia jantung, menurunkan denyut jantung. ${ }^{11}$

\section{Pengobatan lain}

Fukuda et al. ${ }^{20}$ meneliti tentang efek dari statin pada pasien dengan HFPEF yang diterapi dengan beta bloker atau CCB, ACE inhibitor atau ARB. Enam puluh delapan pasien diberikan terapi statin dan sisanya 69 pasien tidak diberikan statin. Penelitian ini menunjukkan bahwa penggunaan statin mempunyai efek menguntungkan pada grup pasien ini, menurunkan $20 \%$ angka kematian (angka kematian 0,06 vs 0,62, $\mathrm{p}=0,005)$. Ada juga kecenderungan menurunnya angka rawat inap dengan penyakit kardiovaskular $(\mathrm{p}=0,082)$. Penggunaaan obat lainnya tidak mempunyai efek yang menguntungkan. Efek menguntungkan dari penggunaan statin pada pasien HFPEF tidak hanya karena stabilisasi plak pada arteri koroner saja, tetapi juga karena statin dapat mengurangi massa ventrikel kiri dan mengurangi fibrosis. mengontrol tekanan darah, menekan (mengurangi) hipertrofi ventrikel kiri dan memperbaiki relaksasi. Penggunaan ARB dosis tinggi disarankan untuk mengurangi angka rawat inap.

Menurut panduan ACC/AHA kunci dari penanganan pasien dengan HFPEF meliputi kontrol hidrasi secara hati-hati, optimalisasi terapi anti hipertensi dan pada kasus AF, restorasi dan pemeliharaan irama sinus atau kontrol irama ventrikel pada pasien dengan aritmia persisten. Dokter juga harus mengingat tentang revaskularisasi pada pasien simtomatik, jika diperkirakan terjadi iskemik yang menyebabkan terjadinya disfungsi diastolik.

Penanganan HFPEF harus dilakukan secara optimal untuk meningkatkan prognosis pada pesien. Pada intinya penanganan HFPEF harus didasarkan pada :

- Penanganan kausatif: hipertensi, diabetes melitus tipe II, aritmia (pencegahan takiaritmia dan jika memungkinkan mempertehankan irama sinus), penyakit jantung iskemik, penurunan berat badan, pembatasan diet garam;
Tabel 2. Dasar Patofisiologi dan Terapi pada HFPEF7

\begin{tabular}{ll}
\hline Dasar Patofisiologi & Terapi \\
\hline Kontrol hipertensi & ACE inhibitor \\
& AT1 reseptor blocker \\
Menurunkan denyut jantung (pertahankan irama sinus) & Antagonis aldosteron \\
& Beta blocker \\
Menormalkan kontraksi atrium (fibrilasi atrium) & Calcium channel blocker (non-dihidropiridin) \\
Mengurangi volume overload (tekanan vena) & Digoxin (kontroversial) \\
& Diuretik \\
Pencegahan iskemia & Antagonis aldosteron \\
& Restriksi garam dan cairan \\
& Beta blocker \\
& Calcium channel blocker (non-dihidropiridin) \\
& Nitrat \\
& Revaskularisasi \\
\hline
\end{tabular}

\section{Ringkasan}

Rekomendasi ESC menentukan jenis terapi yang spesifik pada HFPEF. Untuk menurunkan denyut jantung dan meningkatkan distolik direkomendasikan penggunaan beta bloker atau CCB nondihydropyridine. Untuk menghilangkan retensi cairan digunakan diuretik, harus diberikan dengan hati-hati. Selain itu ACE inhibitor digunakan untuk
- Penanganan simptomatik: beta bloker, CCB nondihidropiridin, ACE inhibitor, ARB, diuretik, statin, aldosteron antagonis.

\section{Daftar Pustaka}

1. Dickstein K, Cohen-Solal A, Fillippatos G et al. ESC Guidelines for the diagnosis and treatment of acute and chronic heart 
failure. Eur Heart J, 2008; 29: 2388-2442.

2. Grossman W. Defining diastolic dysfunction. Circulation. 2000; 101: 2020-2021.

3. Van Heerebeek L, Borbly A, Niessen HW et al. Myocardial structure and function differ in systolic and diastolic heart failure. Circulation, 2006; 113: 774-781.

4. Opolski G eds. Kardiologia. 1st Ed. Urban \& Partner, Wroclaw 2003.

5. Nagueh SF, Appleton CP, Gillebert TC et al. Recommendation for the evaluations of the left ventricular diastolic function by echocardiography. Eur J Echocardiogr, 2009; 10: 165-193.

6. Aurigemma GP. Diastolic heart failure: A common and lethal codition by any name. N Engl J Med, 2006; 355: 308-310.

7. Jessup M, Abraham WT, Casey DE et al. ACCF/AHA guidelines for the diagnosis and management of heart failure in adult: $\mathrm{A}$ report of the American College of Cardiology Foundation/ American Heart Association Task Force on Practice Guidelines. Circulation, 2009; 119: 1977-2016.

8. Gandhi SK, Powers JC, Nomeir AM et al. The pathogenesis of acute pulmonary edema associated with hypertension. $\mathrm{N}$ Engl J Med, 2001; 244: 17-22.

9. Dahlof B, Devereux RB, Kjedsen SE et al. Cardiovascular morbidity and mortality in the Losartan intervention For Endpoint reduction in hypertension study (LIFE): A randomised trial againts atenolol. Lancet, 2002; 359: 995-1003.

10. Yusuf S, Pfeffer MA, Swedberg K et al. Effects of candesartan in patients with chonic heart failure and preserved left ventricular ejection fraction: The CHARM-Preserved Trial. Lancet, 2003;362: 771-781.

11. Cleland JGF, Tendera M, Adamus J et al. The perindopril in elderly people with chronic heart failure (PEP-CHF) study. Eur Heart J, 2006; 27: 2338-2345.

12. Solomon SD, Janardhanan R, Verma A et al. ;for the valsartan in Diastolic Dysfunction (VALIDD) Investigators. Effect of angiotensin receptor blockade and antihypertensive drugs on diastolic function in patients with hypertension and diastolic dysfunction: A randomised trial. Lancet, 2007; 369: 20792087.

13. Kostis JB, Davis BR, Cutler J et al. Prevention on heart failure by antihypertensive drug treatment in older person with isolated systolic hypertension. SHEP Cooperative Research Group. JAMA, 1997; 278: 212-216.

14. Ofili EO, Cohen JD, St. Vrain J et al. Effect of treatment of isolated systolic hypertension on left ventricular mass. JAMA. 1998; 278-780.

15. Bergstorm A, Adersson B, Edner $M$ et al. effect of carvedilol on diastolic dysfunction in patients with diastolic heart failure and preserved systolic function. Result of the Swedih Dopplerechocardiographic study (SWEDIC). Eur J Heart Fail, 2004; 6: 453-461.

16. Tendera M, Schneeweiss A, Bartoszewski A et al. The acute response of the left ventricular filling dynamics to intravenous verapamil predicts the changes in exercise tolerance after oral verapamil therapy in patients with hypertropic cardiomyopathy, Eur Heart J. 1993; 14: 410-415.

17. Ghio S, Magrini G Serio A et al. SENIORS investigators. Effects of nebivolol in elderly heart failure patients with or without systolic left ventricular dysfunction: Results of the SENIORS echocardiographic substudy. Eur Heart J, 2006; 27:562-568.

18. The Digitalis Investigation Group. The effect of digoxin on mortality and morbidity in patients with heart failure. N Engl J Med, 1997; 336: 325-533.

19. Kramer K, Kirkman P, Kitzman D et al. Flash pulmonary edema: association with hypertension and reoccurrence despite coronary revascularization. Am Heart J, 2000; 40: 451-455.

20. Fukuda H, Sane D, Brucks $S$ et al. Statin therapy may be associated with lower mortality in patients with diastolic heart failure. A preliminary report. Circulation, 2005; 112: 357-363. 